\title{
33. PETROLOGY AND ORIGIN OF BASALTS OF THE MIDDLE AMERICA TRENCH, SOUTHERN MEXICO TRANSECT ${ }^{1}$
}

\author{
Y. I. Dmitriev, Institute of Geology and Ore Deposits, Petrology, Mineralogy and Geochemistry, \\ USSR Academy of Sciences, Moscow, USSR
}

\section{INTRODUCTION}

The volcanism of Central America, according to current theory (Pichler and Weyl, 1973; Stoiber and Carr, 1974; Hey, 1977), is related to the subduction of the Cocos Plate under the North American lithospheric plate and the melting of ocean crust material in the subduction zone (Green and Ringwood, 1968; Dickinson, 1970, Fitton, 1971).

Since Cocos Plate subduction occurs at the rate of more than $7 \mathrm{~cm} / \mathrm{y}$. (Hey et al., 1977), basalts underlying upper Miocene sediments of the Middle America Trench outer slope, penetrated in Hole 487 (Fig. 1) during Leg 66 (Moore et al., 1979), should have formed far from their present position if current theory is accurate.

Present manifestations of basaltic magmatism in adjacent areas of the Pacific derive from the axial part of the East Pacific Rise, the Galapagos spreading center, and transform fracture zones.

The question arises: Are there analogs of the Middle America Trench basalts among magmatic rock associated with these modern features, or do the trench basalts have some other origin?

\section{HOLE 487 BASALTS}

To answer this question, let us compare the petrological data of Hole 487 basalts, samples of which were provided by the Deep Sea Drilling Project repository at Scripps Institution of Oceanography, with my own and other scientists' published material on magmatic basic rocks of different structural elements in the Pacific segment of the Earth's crust.

Hole 487 was drilled $11 \mathrm{~km}$ from the axis of the Middle America Trench zone, at $15^{\circ} 51.21^{\prime} \mathrm{N}, 99^{\circ} 10.52^{\prime} \mathrm{W}$ and at a water depth of 4764 meters. They reached basalt at 172 meters sub-bottom, under a layer of hemipelagic gray green mud and pelagic brown clay. I studied Samples 487-20-1, 172-173.5 $\mathrm{m}$ and 487-20-2, 173.5$181.5 \mathrm{~m}$.

Based on their petrographic and petrochemical characteristics, I subdivide Hole 487 basalts into two groups, olivine-plagioclase phyric and aphyric basalts (Samples 487-20-1, 2-9 cm, 29-32 cm, 73-78 cm; 487-20-2, 62-64 $\mathrm{cm}, 80-84 \mathrm{~cm}$ ) and plagioclase phyric basalts (Samples $487-20-1,15-19 \mathrm{~cm}, 113-115 \mathrm{~cm}$; 487-20-2, 34-36 cm).

\footnotetext{
${ }^{1}$ Initial Reports of the Deep Sea Drilling Project, Volume 66.
}

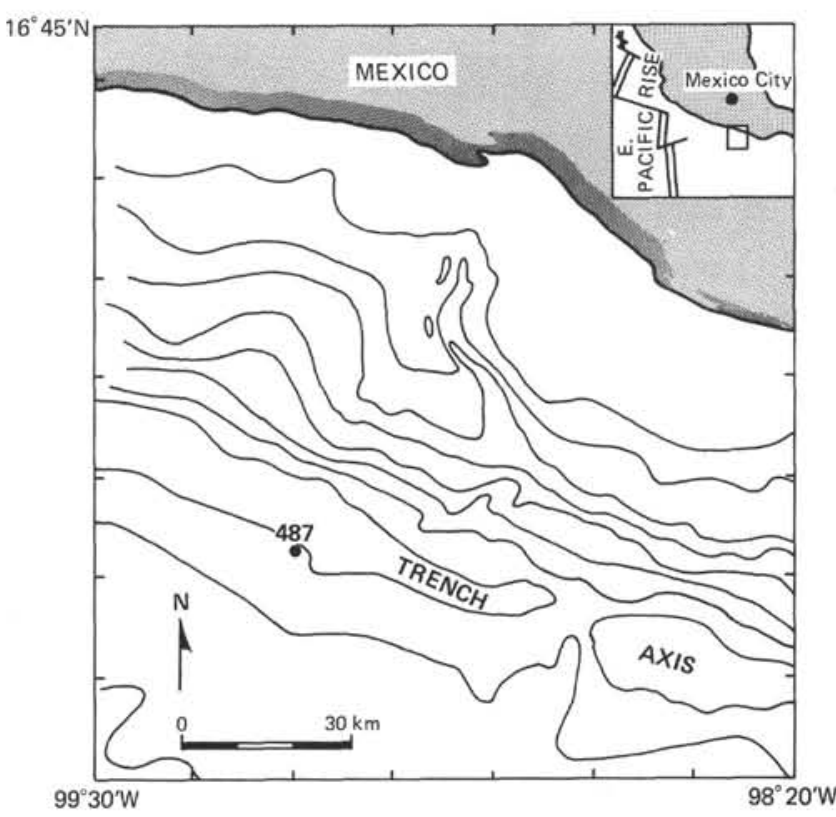

Figure 1. Location map for Hole 487.

Rocks of both groups, according to the ratio $\mathrm{Na}_{2} \mathrm{O}+$ $\mathrm{K}_{2} \mathrm{O} / \mathrm{SiO}_{2}$, derive from tholeiitic basalt magma.

Olivine-plagioclase phyric and aphyric basalts as well as plagioclase phyric basalts have a fine-grained groundmass consisting of a cryptocrystalline matrix, grains of plagioclase, clinopyroxene, olivine, titanomagnetite, spinel, and patches of such secondary minerals as calcite and smectite (Table 1).

The main mineralogical differences between the rocks studied are type and content of phenocrysts. Olivine-plagioclase phyric basalts contain as much as 11 to $12 \%$ plagioclase phenocrysts and olivine. Plagioclase phyric basalts contain only 2 to $3 \%$ plagioclase phenocrysts. Although aphyric basalts have no phenocrysts, or contain only a few grains, they are considered together with olivine-plagioclase phyric basalts because of their virtual identity in chemical composition.

The texture of the groundmass of basalts is mainly microlitic and pilotaxitic.

The comparison of rock-forming mineral compositions of olivine-plagioclase phyric and plagioclase phyric basalts (Tables 2-6) shows that plagioclase phyric basalts have more calcic plagioclase in the groundmass, somewhat more ferruginous clinopyroxene, clearly more ferruginous olivine, titanomagnetite with higher $\mathrm{TiO}_{2}$ 


\section{Y, I. DMITRIEV}

Table 1. Modal composition of basalts, Hole 487 (vol.\%).

\begin{tabular}{|c|c|c|c|c|c|c|c|c|c|c|c|c|}
\hline \multirow[b]{2}{*}{$\begin{array}{c}\text { Sample } \\
\text { (interval in } \mathrm{cm} \text { ) }\end{array}$} & \multicolumn{8}{|c|}{ Olivine-Plagioclase Phyric and Aphyric Basalts } & \multicolumn{4}{|c|}{ Plagioclase Phyric Basalts } \\
\hline & $\begin{array}{c}487-20-1 \\
2-9\end{array}$ & $\begin{array}{l}487-20-1 \\
29-32\end{array}$ & $\begin{array}{c}487-20-1^{a} \\
45-49\end{array}$ & $\begin{array}{c}487-20-1 \\
73-78\end{array}$ & $\begin{array}{l}487-20-2 \\
50-56\end{array}$ & $\begin{array}{c}487-20-2 \\
62-64\end{array}$ & $\begin{array}{l}487-20-2 \\
80-84\end{array}$ & $\begin{array}{c}\text { Average } \\
\text { of } 7\end{array}$ & $\begin{array}{l}487-20-1 \\
15-19\end{array}$ & $\begin{array}{l}487-20-1 \\
113-115\end{array}$ & $\begin{array}{c}487-20-2 \\
34-36\end{array}$ & $\begin{array}{l}\text { Average } \\
\text { of } 3\end{array}$ \\
\hline \multicolumn{13}{|l|}{ Phenocrysts: } \\
\hline plagioclase & 4.5 & 2.9 & - & 1.8 & 1.7 & 4.7 & 11.6 & 3.9 & 2.3 & 1.6 & 0.6 & 1.5 \\
\hline olivine & 2.3 & 0.9 & - & 0.7 & r.g. & 1.2 & r.g. & 0.4 & - & - & - & - \\
\hline spinel & r.g. & - & - & - & r.g. & - & - & r.g. & 0.2 & r.g. & - & 0.1 \\
\hline \multicolumn{13}{|l|}{ Groundmass: } \\
\hline plagioclase & 40.4 & 39.4 & 37.9 & 34.7 & 28.3 & 26.6 & 31.5 & 34.1 & 34.7 & 44.6 & 26.0 & 35.1 \\
\hline clinopyroxene & 49.6 & 3.3 & 2.8 & 3.2 & 63.1 & 3.4 & 2.5 & 22.6 & 2.1 & 50.0 & 4.1 & 18.7 \\
\hline olivine & - & - & - & - & 0.4 & - & - & 0.1 & - & - & - & - \\
\hline titanomagnetite & 3.1 & \multicolumn{2}{|c|}{ in matrix } & & 1.0 & \multicolumn{2}{|c|}{ in matrix } & 0.6 & \multicolumn{2}{|c|}{ in matrix } & \multicolumn{2}{|c|}{ in matrix } \\
\hline secondary minerals & 1.8 & - & - & - & 5.5 & - & - & 1.0 & & & & \\
\hline matrix & - & 53.5 & 59.3 & 59.6 & - & 34.1 & 54.4 & 37.4 & 60.7 & 3.8 & 69.3 & 44.6 \\
\hline
\end{tabular}

Note: r.g. = rare grains.

a Aphyric basalt,

Table 2. Plagioclase in basalts, Hole 487.

\begin{tabular}{|c|c|c|c|c|c|}
\hline & \multicolumn{3}{|c|}{$\begin{array}{c}\text { Olivine-Plagioclase } \\
\text { Phyric Basalts } \\
\text { Sample } 487-20-2,50-56 \mathrm{~cm}\end{array}$} & \multicolumn{2}{|c|}{$\begin{array}{c}\text { Plagioclase Phyric Basalts } \\
\text { Sample } 487-20-1, \\
113-115 \mathrm{~cm} \\
\end{array}$} \\
\hline & \multicolumn{2}{|c|}{ Phenocryst } & \multirow{2}{*}{$\begin{array}{l}\text { Lath in } \\
\text { Groundmass }\end{array}$} & \multirow[b]{2}{*}{ Phenocryst } & \multirow{2}{*}{$\begin{array}{l}\text { Lath in } \\
\text { Groundmass }\end{array}$} \\
\hline & Core & Fringe & & & \\
\hline $\mathrm{SiO}_{2}$ & 49.4 & 47.1 & 49.6 & 45.2 & 47.8 \\
\hline $\mathrm{TiO}_{2}$ & - & - & - & - & 0.1 \\
\hline $\mathrm{Al}_{2} \mathrm{O}_{3}$ & 33.9 & 32.8 & 30.3 & 36.2 & 34.3 \\
\hline $\mathrm{FeO}$ & 0.38 & 0.34 & 0.64 & 0.35 & 1.5 \\
\hline $\mathrm{MgO}$ & 0.17 & 0.28 & 0.36 & 0.25 & 0.12 \\
\hline $\mathrm{CaO}$ & 18.0 & 17.5 & 15.4 & 17.1 & 16.1 \\
\hline $\mathrm{Na}_{2} \mathrm{O}$ & 1.1 & 1.7 & 2.4 & 1.5 & 2.2 \\
\hline Total & 99.95 & 99.72 & 98.7 & 100.6 & 102.12 \\
\hline \multicolumn{6}{|c|}{ Cations on 8 Oxygen } \\
\hline $\mathrm{Si}$ & 2.138 & 2.175 & 2.298 & 2.068 & 2.158 \\
\hline $\mathrm{Ti}$ & - & - & - & - & 0.004 \\
\hline $\mathrm{Al}$ & 1.841 & 1.785 & 1.655 & 2.062 & 1.825 \\
\hline $\mathrm{Fe}$ & 0.014 & 0.013 & 0.025 & 0.013 & 0.057 \\
\hline $\mathrm{Mg}$ & 0.001 & 0.019 & 0.025 & 0.017 & 0.008 \\
\hline $\mathrm{Ca}$ & 0.889 & 0.866 & 0.681 & 0.838 & 0.778 \\
\hline $\mathrm{Na}$ & 0.098 & 0.152 & 0.215 & 0.133 & 0.193 \\
\hline$\% \mathrm{Ab}$ & 9.8 & 14.5 & 22.7 & 13.3 & 18.6 \\
\hline$\%$ An & 90.2 & 85.5 & 77.3 & 86.7 & 81.4 \\
\hline Name & anorthite & bitownite & bitownite & bitownite & bitownite \\
\hline
\end{tabular}

Note: Chemical compositions of rock-forming minerals in basalts in Hole 487 were determined on an electron microprobe by G. N. Muravitskaya of the Institute of Geology of Ore Deposits, Petrography, Mineralogy and Geochemistry of the USSR Academy of Sciences.

content, and spinel with relatively low $\mathrm{Mg}$ and $\mathrm{Cr}$ content.

As a whole, except for a higher anorthite content in the plagioclase groundmass, these data suggest a more differentiated character for plagioclase phyric basalts in relation to olivine-plagioclase phyric and aphyric basalts.

Other evidence for greater differentiation of the plagioclase phyric basalts is iron enrichment. The $\left(\mathrm{FeO}^{*} /\right.$ $\left.\mathrm{FeO}^{*}+\mathrm{MgO}\right) / \times 100$ ratio $\left(\mathrm{FeO}^{*}\right.$ is total $\mathrm{Fe}$ as $\left.\mathrm{FeO}\right)$ in these rocks averages 51.1, whereas in olivine-plagioclase phyric basalts the mean value of this coefficient is 50.8. The main distinction of plagioclase phyric basalts, however, lies in the significantly higher $\mathrm{Al}_{2} \mathrm{O}_{3}$ content, which exceeds $17 \%$; that is, plagioclase-phyric basalts are high-alumina rocks (Table 7 ). The high-alumina
Table 3. Clinopyroxenes in basalts, Hole 487.

\begin{tabular}{|c|c|c|c|c|}
\hline \multirow[b]{2}{*}{$\mathrm{SiO}_{2}$} & \multicolumn{2}{|c|}{$\begin{array}{c}\text { Olivine- } \\
\text { Plagioclase } \\
\text { Phyric Basalts } \\
\text { Sample } 487-20-2 \text {, } \\
50-56 \mathrm{~cm}\end{array}$} & \multicolumn{2}{|c|}{$\begin{array}{c}\text { Plagioclase } \\
\text { Phyric } \\
\text { Basalts } \\
\text { Sample } 487-20-1, \\
113-115 \mathrm{~cm}\end{array}$} \\
\hline & 49.7 & 50.7 & 53.4 & 51.3 \\
\hline $\mathrm{TiO}_{2}$ & 0.83 & 0.85 & 1.0 & 1.0 \\
\hline $\mathrm{Al}_{2} \mathrm{O}_{3}$ & 3.3 & 4.8 & 3.7 & 3.3 \\
\hline $\mathrm{FeO}$ & 11.5 & 8.6 & 11.7 & 14.5 \\
\hline $\mathrm{MnO}$ & 0.19 & 0.25 & 0.11 & 0.31 \\
\hline $\mathrm{MgO}$ & 14.7 & 14.7 & 13.3 & 15.1 \\
\hline $\mathrm{CaO}$ & 20.1 & 20.0 & 18.3 & 13.3 \\
\hline $\mathrm{Na}_{2} \mathrm{O}$ & - & - & 0.7 & 0.3 \\
\hline \multirow[t]{2}{*}{ Total } & 100.32 & 99.9 & 102.21 & 99.11 \\
\hline & \multicolumn{3}{|c|}{ Cations on 6 Oxygen } & \\
\hline $\mathrm{Si}$ & 2.125 & 1.879 & 1.944 & 1.932 \\
\hline $\mathrm{Ti}$ & 0.027 & 0.024 & 0.027 & 0.028 \\
\hline $\mathrm{Al}$ & 0.166 & 0.210 & 0.159 & 0.147 \\
\hline $\mathrm{Fe}$ & 0.411 & 0.266 & 0.356 & 0.456 \\
\hline $\mathrm{Mn}$ & 0.007 & 0.008 & 0.003 & 0.010 \\
\hline $\mathrm{Mg}$ & 0.937 & 0.812 & 0.721 & 0.847 \\
\hline $\mathrm{Ca}$ & 0.921 & 0.794 & 0.714 & 0.536 \\
\hline $\mathrm{Na}$ & - & - & 0.049 & 0.022 \\
\hline$\%$ En & 37.9 & 42.6 & 36.5 & 42.8 \\
\hline$\%$ Wo & 37.4 & 41.7 & 38.7 & 28.2 \\
\hline$\%$ Fs & 24.6 & 15.7 & 24.8 & 29.0 \\
\hline Name & augite & augite & augite & augite \\
\hline
\end{tabular}

character of plagioclase phyric basalts is also evident in the chemistry of rock-forming minerals. A higher $\mathrm{Al}_{2} \mathrm{O}_{3}$ content is typical not only for feldspar of plagioclase phyric basalts but also for spinel, titanomagnetite, and even for olivine.

From a chemical viewpoint, aphyric basalts are very similar to olivine-plagioclase phyric basalts, and what differences there are are in keeping with the mineralogical composition of the rocks and their position in cross section. For example, the lower $\mathrm{CaO}$ content in aphyric basalts as compared with olivine-plagioclase phyric basalts reflects the absence of plagioclase phenocrysts enriched with anorthite in the former. Aphyric basalts are also distinctive because of their higher $\mathrm{MgO}$ and $\mathrm{Cr}_{2} \mathrm{O}_{3}$ 
Table 4. Olivines in basalts, Hole 487.

\begin{tabular}{|c|c|c|c|}
\hline & \multicolumn{2}{|c|}{$\begin{array}{c}\text { Olivine- } \\
\text { Plagioclase } \\
\text { Phyric Basalts } \\
\text { Sample } 487-20-2 \text {, } \\
50-56 \mathrm{~cm} \\
\end{array}$} & \multirow{2}{*}{$\begin{array}{c}\text { Plagioclase } \\
\text { Phyric Basalts } \\
\text { Sample } 487-20-1 \\
113-115 \mathrm{~cm}\end{array}$} \\
\hline & Fringe & Core & \\
\hline $\mathrm{SiO}_{2}$ & 40.6 & 40.8 & 38.3 \\
\hline $\mathrm{TiO}_{2}$ & - & - & 0.11 \\
\hline $\mathrm{Al}_{2} \mathrm{O}_{3}$ & - & - & 1.9 \\
\hline $\mathrm{FeO}$ & 10.4 & 10.4 & 15.7 \\
\hline $\mathrm{MnO}$ & 0.12 & 0.13 & 0.21 \\
\hline $\mathrm{MgO}$ & 47.8 & 48.2 & 41.8 \\
\hline $\mathrm{CaO}$ & 0.46 & 0.41 & 1.7 \\
\hline $\mathrm{NiO}$ & 0.14 & 0.22 & - \\
\hline \multirow[t]{2}{*}{ Total } & 99.52 & 100.16 & 99.73 \\
\hline & \multicolumn{3}{|c|}{ Cations on 4 Oxygen } \\
\hline $\mathrm{Si}$ & 1.003 & 1.002 & 0.973 \\
\hline $\mathrm{Ti}$ & - & - & 0.002 \\
\hline $\mathrm{Al}$ & - & - & 0.057 \\
\hline $\mathrm{Fe}$ & 0.215 & 0.213 & 0.333 \\
\hline $\mathrm{Mn}$ & 0.002 & 0.003 & 0.005 \\
\hline $\mathrm{Mg}$ & 1.761 & 1.764 & 1.581 \\
\hline $\mathrm{Ca}$ & 0.012 & 0.011 & 0.046 \\
\hline $\mathrm{Ni}$ & 0.003 & 0.004 & - \\
\hline$\%$ Fo & 88.5 & 88.6 & 79.0 \\
\hline$\% \mathrm{Fa}$ & 11.5 & 11.4 & 21.0 \\
\hline Name & \multicolumn{2}{|c|}{ chrysolite } & chrysolite \\
\hline
\end{tabular}

Table 5. Titanomagnetite in basalts, Hole 487.

\begin{tabular}{|c|c|c|c|c|c|}
\hline \multirow[b]{2}{*}{$\mathrm{SiO}_{2}$} & \multicolumn{3}{|c|}{$\begin{array}{c}\text { Olivine-Plagioclase } \\
\text { Phyric Basalts } \\
\text { Sample } 487-20-2 \\
50-56 \mathrm{~cm}\end{array}$} & \multicolumn{2}{|c|}{$\begin{array}{l}\text { Plagioclase } \\
\text { Phyric } \\
\text { Basalts } \\
\text { Sample } \\
487-20-1 \text {, } \\
113-115 \mathrm{~cm}\end{array}$} \\
\hline & 1.3 & 1.8 & 2.3 & 9.8 & 9.2 \\
\hline $\mathrm{TiO}_{2}$ & 16.3 & 16.1 & 16.1 & 17.5 & 17.5 \\
\hline $\mathrm{Al}_{2} \mathrm{O}_{3}$ & 2.4 & 3.2 & 3.3 & 4.0 & 6.1 \\
\hline $\mathrm{FeO}$ & 73.0 & 72.7 & 73.0 & 59.5 & 57.0 \\
\hline $\mathrm{MnO}$ & 0.43 & 0.43 & 0.51 & 0.51 & 0.6 \\
\hline $\mathrm{MgO}$ & 2.0 & 1.3 & 1.2 & 1.4 & 0.9 \\
\hline $\mathrm{CaO}$ & 0.36 & 0.42 & 0.48 & 1.8 & 2.1 \\
\hline $\mathrm{V}_{2} \mathrm{O}_{5}$ & 0.44 & 0.47 & 0.42 & n.d. & n.d. \\
\hline Total & 96.11 & 96.88 & 97.63 & 94.51 & 93.4 \\
\hline
\end{tabular}

Note: The determination of the unit cell dimension of magnetic ore mineral from Sample 487-20-1, 113-115 cm, performed by M. T. Dmitrieva, Institute of Geology of Ore Deposits, Petrography, Mineralogy and Geochemistry of the USSR Academy of Sciences, shows that according to the value of this parameter, $a=8.405 \pm 0.005 \AA$, the mineral is almost pure magnetite $(a=8.395-$ $8.40 \AA$ A ).

content and their lower degree of iron oxidation. A genetic relation between aphyric, olivine-plagioclase phyric, and plagioclase phyric basalts is revealed by the relationship between their mineral and chemical composition and their position in the cross section of the hole (Fig. 2), though the latter may be significantly distorted by displacement during drilling. In somewhat generalized form, the distribution of these varieties of basalt in the lower part of Hole $\mathbf{4 8 7}$ is as follows:

\begin{tabular}{lc}
\hline \multicolumn{1}{c}{ Core 20, Section 1 } & $\begin{array}{c}\text { Depth from the Top of } \\
\text { the Section }(\mathrm{cm})\end{array}$ \\
\hline $\begin{array}{l}\text { olivine-plagioclase phyric basalt } \\
\text { plagioclase phyric basalt }\end{array}$ & $0-15$ \\
olivine-plagioclase phyric and & $15-23$ \\
$\quad$ aphyric basalts & $23-72$ \\
olivine-plagioclase phyric basalt & $72-110$ \\
plagioclase phyric basalt & $110-122$ \\
drilling breccia & $122-150$ \\
\multicolumn{1}{c}{ Core 20, Section 2 } & \\
drilling breccia & $0-26$ \\
plagioclase phyric basalt & \\
olivine-plagioclase phyric basalt & $26-45$ \\
\hline
\end{tabular}

The relationship between aphyric, plagioclase phyric, and olivine-plagioclase phyric basalts is clearest in the upper part of Core 20, Section 1, from 0 to $72 \mathrm{~cm}$.

In this series (also bottom to top) one can see (1) an increase in phenocryst and $\mathrm{CaO}$ content, (2) enrichment of rocks in iron $\left[\left(\mathrm{Fe}^{*} / \mathrm{FeO}^{*}+\mathrm{MgO}\right) \times 100\right]$, and (3) increase in the degree of iron oxidization in basalts $\left[\left(\mathrm{Fe}_{2} \mathrm{O}_{3}\right)\right.$ $\left.\left.\left.\mathrm{Fe}_{2} \mathrm{O}_{3}+\mathrm{FeO}\right) \times 100\right)\right]$.

It is possible that the variations of mineral and chemical composition are related to the differentiation processes inside the lava flow, or sheet. Flotation of plagioclase crystals and their accumulation in the upper parts of basaltic bodies have been discussed with relation to drilling in the Philippine Sea (Dmitriev et al., 1979).

The increased value of the ferruginity (fractionation) coeffficient $\left[\left(\mathrm{FeO}^{*} / \mathrm{FeO}^{*}+\mathrm{MgO}\right) \times 100\right]$ in the upper parts of differentiated basaltic bodies is a well-known

Table 6. Spinels in basalts, Hole 487.

\begin{tabular}{lcc}
\hline & $\begin{array}{c}\text { Olivine-Plagioclase } \\
\text { Phyric Basalts } \\
\text { Sample 487-20-2, } \\
50-56 \mathrm{~cm}\end{array}$ & $\begin{array}{c}\text { Plagioclase } \\
\text { Phyric Basalts } \\
\text { Sample 487-20-1, } \\
113-115 \mathrm{~cm}\end{array}$ \\
\hline $\mathrm{SiO}_{2}$ & 0.6 & 5.3 \\
$\mathrm{TiO}_{2}$ & 0.37 & 0.36 \\
$\mathrm{Al}_{2} \mathrm{O}_{3}$ & 30.7 & 34.8 \\
$\mathrm{FeO}$ & 15.8 & 15.0 \\
$\mathrm{MnO}$ & 0.14 & - \\
$\mathrm{MgO}$ & 17.6 & 14.4 \\
$\mathrm{CaO}$ & 0.27 & 1.2 \\
$\mathrm{Cr}{ }_{2} \mathrm{O}_{3}$ & 32.8 & 30.2 \\
$\mathrm{Total}$ & 98.28 & 101.38 \\
& Cations & \\
$\mathrm{Si}$ & 0.053 & 0.443 \\
$\mathrm{Ti}$ & 0.025 & 0.023 \\
$\mathrm{Al}$ & 3.222 & 3.430 \\
$\mathrm{Fe}$ & 1.176 & 1.049 \\
$\mathrm{Mn}$ & 0.011 & - \\
$\mathrm{Mg}$ & 2.335 & 1.774 \\
$\mathrm{Ca}$ & 0.026 & 0.108 \\
$\mathrm{Cr}$ & 2.309 & 1.995 \\
$\mathrm{Fe} / \mathrm{Fe}+\mathrm{Mg}$ & 0.335 & 0.372 \\
\hline
\end{tabular}


Table 7. Chemical composition of basalts, Hole 487 (wt.\%).

\begin{tabular}{|c|c|c|c|c|c|c|c|c|}
\hline \multirow[b]{2}{*}{$\begin{array}{c}\text { Sample } \\
\text { (interval in } \mathrm{cm} \text { ) }\end{array}$} & \multicolumn{5}{|c|}{ Olivine-Plagioclase Phyric and Aphyric Basalts } & \multicolumn{3}{|c|}{ Plagioclase Phyric Basalts } \\
\hline & $\begin{array}{c}487-20-1 \\
2-9\end{array}$ & $\begin{array}{c}487-20-1 \\
45-49\end{array}$ & $\begin{array}{c}487-20-2 \\
50-56\end{array}$ & $\begin{array}{c}487-20-2 \\
80-84\end{array}$ & $\begin{array}{c}\text { Average } \\
\text { of } 7\end{array}$ & $\begin{array}{c}487-20-1 \\
15-19\end{array}$ & $\begin{array}{l}487-20-1 \\
113-115\end{array}$ & $\begin{array}{c}\text { Average } \\
\text { of } 2\end{array}$ \\
\hline $\mathrm{SiO}_{2}$ & 47.80 & 48.60 & 47.70 & 47.90 & 48.0 & 47.20 & 48.20 & 47.7 \\
\hline & 0.86 & 0.93 & 0.86 & 0.88 & 0.88 & 0.89 & 0.87 & 0.88 \\
\hline $\mathrm{Al}_{2} \mathrm{O}_{3}$ & 16.47 & 16.40 & 16.38 & 16.70 & 16.49 & 18.00 & 17.10 & 17.6 \\
\hline $\mathrm{Fe}_{2} \mathrm{O}_{3}$ & 4.82 & 1.33 & 4.35 & 2.24 & 3.19 & 2.75 & 3.72 & 3.24 \\
\hline & 3.94 & 7.35 & 4.45 & 7.03 & 5.69 & 6.08 & 5.20 & 5.64 \\
\hline $\mathrm{MnO}$ & 0.16 & 0.13 & 0.55 & 0.16 & 0.25 & 0.11 & 0.11 & 0.11 \\
\hline $\mathrm{MgO}$ & 6.97 & 9.23 & 7.54 & 9.44 & 8.30 & 8.43 & 7.94 & 8.19 \\
\hline $\mathrm{CaO}$ & 13.99 & 12.78 & 14.02 & 12.82 & 13.40 & 13.14 & 12.67 & 12.91 \\
\hline & 2.21 & & 2.1 & & 2.0 & 1.87 & 2.08 & 1.98 \\
\hline $\mathrm{K}_{2} \mathrm{O}$ & 0.19 & 0.10 & 0.18 & 0.074 & 0.14 & 0.10 & 0.10 & 0.10 \\
\hline $\mathrm{H}_{2} \mathrm{O}^{-}$ & - & - & - & - & - & - & 0.28 & 0.14 \\
\hline $\mathrm{H}_{2} \mathrm{O}^{+}$ & 2.21 & 0.98 & 1.44 & 0.87 & 1.38 & 1.01 & 1.72 & 1.37 \\
\hline $\mathrm{CO}_{2}$ & - & 0.15 & - & - & 0.0 & 0. & - & 0.28 \\
\hline $\mathrm{P}_{2} \mathrm{O}_{5}$ & - & 0.07 & - & 0.09 & 0.0 & 0.03 & 0.04 & 0.04 \\
\hline $\mathrm{Li}_{2} \mathrm{O}$ & n.d. & 0.0016 & n.d. & 0.0013 & 0.0015 & 0.0013 & & \\
\hline $\mathrm{Rb}_{2} \mathrm{O}$ & n.d. & 0.00 & n.d. & 0.0 & 0.0 & 0.0 & 0.00 & 0.0005 \\
\hline $\mathrm{Cs}_{2} \mathrm{O}$ & n.d. & 0.0006 & n.d. & & & 0.0 & 0.0006 & 0.0005 \\
\hline & 0.02 & 0.02 & 0.02 & 0.0 & 0.0 & 0.0 & 0.03 & 0.03 \\
\hline $\mathrm{Cl}$ & 0.14 & 0.03 & 0.19 & 0.07 & 0.1 & 0.04 & 0.04 & 0.04 \\
\hline s & 0.02 & 0.06 & 0.02 & 0.06 & 0.0 & 0.06 & 0.02 & 0.04 \\
\hline $\mathrm{Cr}_{2} \mathrm{O}_{3}$ & 0.058 & 0.06 & 0.019 & 0.05 & 0.05 & 0.06 & n.d. & 0.06 \\
\hline $\mathrm{v}_{2} \mathrm{O}_{5}$ & 0.046 & 0.04 & 0.02 & 0.01 & 0.03 & 0.05 & n.d. & 0.05 \\
\hline Total & 99.90 & 100.17 & 99.86 & 100.27 & 100.04 & 100.24 & 100.29 & 100.40 \\
\hline
\end{tabular}

Note: Chemical analyses of basalts in Hole 487 were carried out by Y. V. Dolinina, Institute of Geology of Ore Deposits, Petrography, Mineralogy and Geochemistry of the USSR Academy of Sciences. a Aphyric basalt.
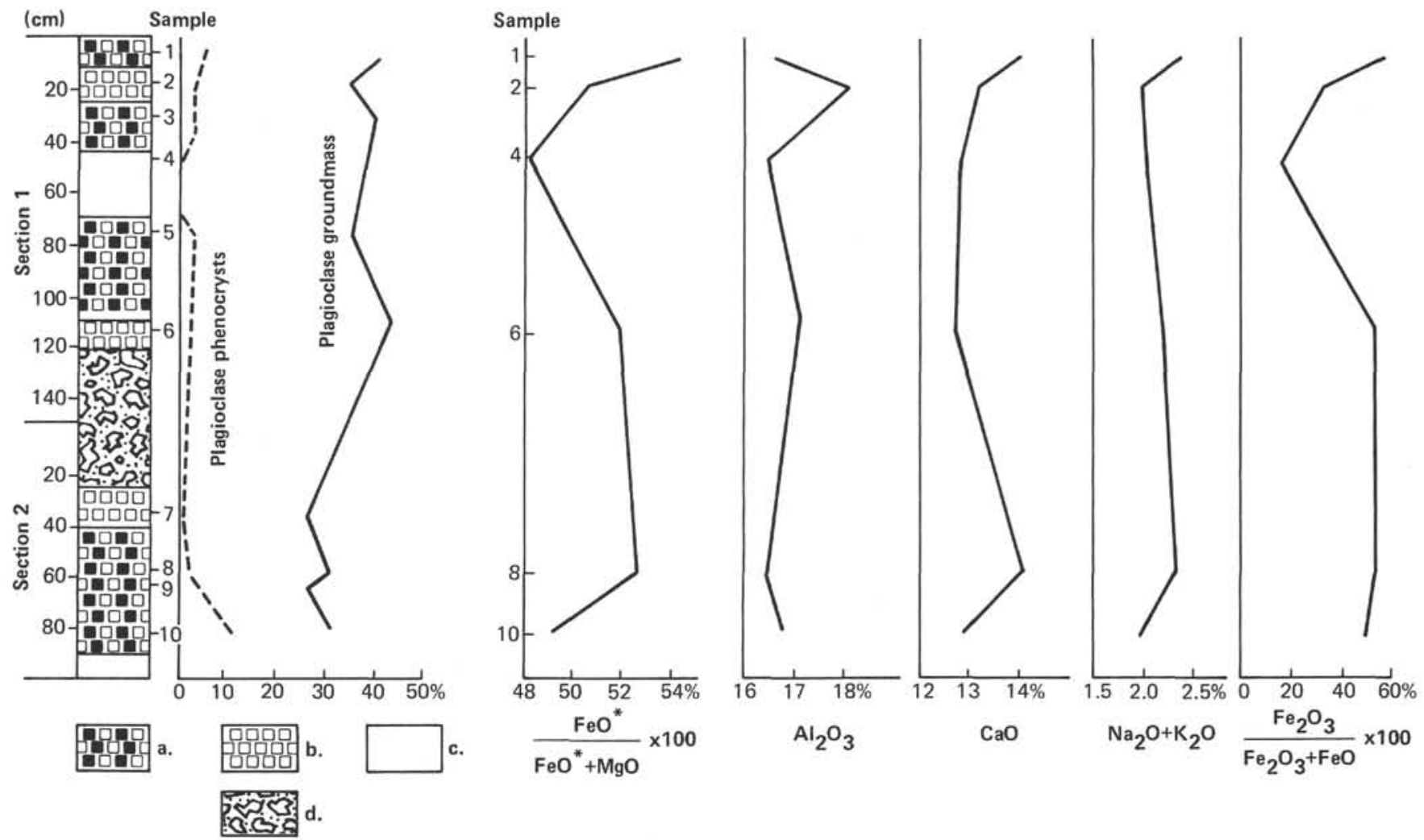

Figure 2. Variations of basalt composition in cross section in Hole 487. $(\mathrm{a}=$ olivine-plagioclase phyric basalts, $\mathrm{b}=$ plagioclase phyric basalts, $\mathrm{c}=$ aphyric basalts, $\mathrm{d}=$ basaltic breccia. Samples: $1=487-20-1,2-9 \mathrm{~cm} ; 2=487-20-1,15-19 \mathrm{~cm} ; 3=487-20-1,29-32 \mathrm{~cm} ; 4=487-20-1,45-49$ $\mathrm{cm} ; 5=487-20-1,73-78 \mathrm{~cm} ; 6=487-20-1,113-115 \mathrm{~cm} ; 7=487-20-2,34-36 \mathrm{~cm} ; 8=487-20-2,50-56 \mathrm{~cm} ; 9=487-20-2,62-64 \mathrm{~cm} ; 10=$ $487-20-2,80-84 \mathrm{~cm}$. 
fact, as is the enrichment of the same parts of basaltic sheets and sills by volatile components. With regard to the latter, the degree of iron oxidation increases beginning at the horizon of aphyric basalts and there are about $0.6 \%$ vesicles (former gas bubbles) in olivine-plagioclase phyric basalt in the top of the cross section. In the lower part of the cross section, plagioclase phyric, olivine-plagioclase phyric, and aphyric basalts contain no such vesicles.

The decrease in quantity of plagioclase phenocrysts and the absence of olivine phenocrysts in plagioclase phyric basalts in the upper part of the presumed basaltic body may be related to the dissolution of phenocrysts due to their disequilibrium with the more differentiated melt of this zone.

On the basis of these data we may conclude that aphyric, olivine-plagioclase phyric, and plagioclase phyric basalts are derivatives of a common tholeiitic melt, differentiated in the body of basaltic flow or sheet after eruption on the seafloor.

The interpretation of the sequence aphyric and olivine-plagioclase phyric basalts, olivine-plagioclase phyric basalts, and plagioclase phyric basalts as a series reflecting differentiation inside the basaltic flow or sheet is contradicted by the thickness (less than $1 \mathrm{~m}$ ) of the presumed basaltic body, which should preclude significant differentiation.

In the lower part of the cross section one can also see the sequence (from top to bottom) olivine-plagioclase phyric basalts, plagioclase phyric basalts, and olivineplagioclase phyric basalts (without aphyric basalts), but the regular variations in rock composition observed in the upper part of the cross section are absent. It is possible that the original relationship between rocks in the lower part of the cross section was disturbed during drilling, when a rather thick $(54 \mathrm{~cm})$ layer of basalt that had disintegrated during drilling (Samples 487-20-1, $122-150 \mathrm{~cm}$ and $487-20-2,0-26 \mathrm{~cm}$ ) was formed.

Thus the data seems to indicate that basalts in Hole 487 comprise at least two lava flows or sheets.

\section{OTHER EASTERN PACIFIC OCEAN FLOOR BASALTS}

To explain the genesis of basalts exposed in Hole 487, on the seaward side of the Middle America Trench, let us compare data about their composition with similar materials about basalts of other morphostructures in the Eastern Pacific.

Let us begin with a comparison between rock associations in the Middle America Trench, which consists of normal and high-alumina basalts, and those of tholeiitic basalts of different morphostructures in the Pacific; I omit consideration of basaltic series in ocean islands with an alkaline affinity.

In the Galapagos spreading center, according to my material on Holes 424 and 425 of Leg 54 (Dmitriev, in press) and the data of other investigators (Anderson et al., 1975; Rudnik, 1976; Yeats et al., 1973), the following rocks in the tholeiitic series occur: high-alumina basalts, normal basalts, Fe-basalts. There are also alkalic basalts on seamounts in the Galapagos zone of spreading.

In the Siqueiros transform fracture zone, according to my study of samples from Hole 427, Leg 54 (Dmitriev, in press) and to other data (Batiza et al., 1977), there are high-alumina, normal, and Fe-basalts of tholeiitic series as well as alkalic basalts.

On the flanks of the East Pacific Rise, according to my investigation (Dmitriev, in press) of Holes 419, 420, 422 , and 428, Leg 54, and the results of Leg 16 (Yeats et al., 1973), only normal and Fe-basalts of tholeiitic series occur.

All these findings indicate that no direct correspondence exists between associations of rocks in Hole 487 and the basaltic associations of other morphostructures of adjacent regions of the Pacific. In zones of spreading and zones of transform fractures, basaltic associations are more diverse then in Hole 487, for they comprise along with normal and high-alumina basalts, tholeiitic Fe-basalts and alkalic basalts as well. On the flanks of the East Pacific Rise, on the other hand, high-alumina basalts were not observed; instead normal tholeiitic basalts associate with $\mathrm{Fe}$-basalts.

The peculiarity of the associations of normal and high-alumina basalts in Hole 487 becomes more obvious when we compare their average chemical composition with corresponding data on normal and high-alumina basalts of the Galapagos spreading zone, Siqueiros transform fracture zone, and the western flank of the East Pacific Rise (Table 8).

There is a distinct difference between normal basalts of the Middle America Trench and other morphostructures of the East Pacific. As it is clear from Table 8, normal basalts of the Middle America Trench have significantly lower $\mathrm{SiO}_{2}, \mathrm{TiO}_{2}$, and $\mathrm{Na}_{2} \mathrm{O}+\mathrm{K}_{2} \mathrm{O}$ content; a minimum value of $\left(\mathrm{FeO}^{*} / \mathrm{FeO}^{*}+\mathrm{MgO}\right) \times 100$; and higher concentrations of $\mathrm{Al}_{2} \mathrm{O}_{3}$ and $\mathrm{CaO}$ than normal tholeiitic basalts from other morphostructures.

Table 8. Average composition of normal and high-alumina tholeiitic basalts of the Middle America Trench, Hole 487, and other morphostructures of the East Pacific.

\begin{tabular}{|c|c|c|c|c|c|c|c|}
\hline \multirow[b]{2}{*}{ Components } & \multicolumn{4}{|c|}{ Normal Basalts } & \multicolumn{3}{|c|}{ High-Alumina Basalts } \\
\hline & 1 & 2 & 3 & 4 & 5 & 6 & 7 \\
\hline $\mathrm{SiO}_{2}$ & 49.78 & 49.51 & 49.52 & 48.0 & 47.67 & 49.20 & 47.7 \\
\hline $\mathrm{TiO}_{2}^{2}$ & 1.31 & 1.30 & 1.49 & 0.88 & 0.65 & 0.88 & 0.88 \\
\hline $\mathrm{Al}_{2} \mathrm{O}_{3}$ & 15.77 & 14.83 & 14.76 & 16.49 & 18.44 & 17.7 & 17.6 \\
\hline $\mathrm{Fe}_{2} \mathrm{O}_{3}$ & 9.70 & 2.17 & 10.39 & 3.19 & 2.08 & 1.09 & 3.24 \\
\hline $\mathrm{FeO}$ & & 7.55 & & 5.69 & 5.83 & 6.75 & 5.64 \\
\hline $\mathrm{MnO}$ & 0.16 & 0.17 & & 0.25 & 0.13 & 0.14 & 0.11 \\
\hline $\mathrm{MgO}$ & 7.33 & 8.69 & 7.71 & 8.30 & 9.61 & 8.84 & 8.19 \\
\hline $\mathrm{CaO}$ & 12.33 & 12.25 & 11.81 & 13.30 & 12.64 & 12.57 & 12.91 \\
\hline $\mathrm{Na}_{2} \mathrm{O}$ & 2.62 & 3.00 & 2.46 & 2.03 & 2.12 & 2.47 & 1.98 \\
\hline $\mathrm{K}_{2} \mathrm{O}$ & 0.19 & 0.12 & 0.19 & 0.14 & 0.11 & 0.05 & 0.10 \\
\hline $\mathrm{H}_{2} \mathrm{O}$ & & & 1.24 & 1.38 & 0.32 & & 1.37 \\
\hline $\mathrm{P}_{2} \mathrm{O}_{5}$ & 0.12 & 0.16 & 0.15 & 0.04 & 0.07 & 0.10 & \\
\hline Total & 99.31 & 99.75 & 99.72 & 99.79 & 99.63 & 99.79 & \\
\hline $\mathrm{FeO} * /(\mathrm{FeO} *+\mathrm{MgO}) \times 100$ & 57.0 & 52.1 & 60.0 & 50.8 & 44.6 & 46.75 & 51.1 \\
\hline
\end{tabular}

Note: 1, 5-Galapagos spreading zone: 1-average of 19 analyses; 5-average of 4 analyses (on the basis of analyses from Anderson et al., 1975; Dmitriev, in press, analyst, Y. V. Dolinina; Rudnik, 1976; Yeats et al., 1973). 2, 6-Siqueiros Zone of transform fracture: 2 -average of 17 analyses: 6 -average of 2 analyses (on the basis of analyses from Batiza et al., 1977). 3-Western flank of the East Pacific Rise $\left(9^{\circ}-11^{\circ} \mathrm{N}, 105^{\circ}-150^{\circ} \mathrm{W}\right)$ : average of 16 analyses (on the basis of analyses from Dmitriev, in press, analyst, Y. V. Dolinina: Yeats et al., 1973), 4, 7-Middle America Trench, Hole 487: 4-average of 4 analyses; 7-average of 2 analyses. 
The difference between high-alumina trench basalts and basalts of the same type from other ocean morphostructures is less distinct. High-alumina basalts of the Middle America Trench, like the normal basalts of this morphostructure, have a higher $\mathrm{CaO}$ and a lower $\mathrm{Na}_{2} \mathrm{O}$ $+\mathrm{K}_{2} \mathrm{O}$ content, than high-alumina basalts of spreading zone, transform fault or flanks of the mid-oceanic ridge, but the main difference is a significantly higher $\left(\mathrm{FeO} * / \mathrm{FeO}^{*}+\mathrm{MgO}\right) \times 100$ value in trench basalts.

All these data on the chemistry of Middle America Trench basalts support the conclusion that these rocks are not entirely identical to rocks of the same kind in spreading zones, transform faults, and on the flank of the mid-oceanic ridge. Thus the question arises: Is it possible that Middle America Trench basalts originate in the formation of trench-that is, that they erupted locally rather than being brought into the trench zone mechanically by the movement of the lithospheric plates?

If this is the case, we expect that the composition of trench basalts will possess characteristics related to the specific geodynamic conditions of magmatism in these morphostructures which distinguish areas of oceanic tholeiitic magmatism from zones of island arc calcalkaline magmatism.

Let us examine the position of Middle America Trench basalts in Hole 487 with regard to the chemical composition of oceanic tholeiitic basalts, including basalts of other deep sea trenches and island arcs of the Pacific. On the $\mathrm{TiO}_{2} /\left(\mathrm{FeO} * / \mathrm{FeO}^{*}+\mathrm{MgO}\right) \times 100$ diagram (Fig. 3) one can see that basalts of the Middle America Trench, the Mariana Trench, and the Yap Trench occupy a position between basalts of oceanic spreading zones, zones of transform faults, and slopes of the East Pacific Rise on the one hand and basalts of island arcs on the other hand. It is also obvious from this diagram that whereas high-alumina basalts of zones of spreading and transform faults belong to the most primitive rocks of these morphostructures, high-alumina basalts of deep sea trenches, according to the value of $\left(\mathrm{FeO} * / \mathrm{FeO}^{*}+\mathrm{MgO}\right) \times 100$, are more differentiated members of the tholeiitic series.

Deep sea trench basalts occupy the same intermediate position on the $\mathrm{Al}_{2} \mathrm{O}_{3} /\left(\mathrm{FeO} * / \mathrm{FeO}^{*}+\mathrm{MgO}\right) \times 100$ diagram (Fig. 4), but whereas on the previous diagram the distinction of trench basalts is the lower $\mathrm{TiO}_{2}$ content as compared with spreading zone basalts of a similar stage of differentiation, transform fault zones, flanks of the East Pacific Rise, in Figure 4 the distinguishing feature of trench basalts is a higher $\mathrm{Al}_{2} \mathrm{O}_{3}$ concentration.

\section{CONCLUSIONS}

By plotting the chemical analyses of basalts belonging to different morphostructures on the $\mathrm{MgO} / \mathrm{FeO}^{*}$ / $\mathrm{Na}_{2} \mathrm{O}+\mathrm{K}_{2} \mathrm{O}$ diagram (Fig. 5) one can obtain a general notion about the place of normal and high-alumina basalts in deep sea trenches in the basic processes of oceanic tholeiitic magma evolution.

Evidently, the tholeiitic basalts of all Pacific morphostructures form a single trend of evolution in the direc- tion of iron enrichment, which is typical of the tholeiitic basaltic magma in general.

Normal and high-alumina basalts of the Middle America Trench, as well as of the Yap and Mariana trenches, occupy a transitional position between normal tholeiitic basalts and the point at which iron-rich differentiates (Fe-basalts) begin to dominate.

Points reflecting the chemistry of trench basalts are in the right portion of the diagram, which is evidence of an alkali deficit in these rocks as compared with basalts of other oceanic morphostructures.

It is necessary to note that the high-alumina basalts of island arcs even more advanced in the evolutionary series of oceanic tholeiitic magma than high-alumina basalts of the deep sea trenches. This fact confirms the transitional position of tholeiitic trench basalts between basalts of typical oceanic morphostructures and island arc basalts.

The higher $\mathrm{Al}_{2} \mathrm{O}_{3}$ content in deep sea trench basalts and in island arc basalts cannot be the result of the common differentiation of tholeiitic basaltic magma, because in the process of differentiation $\mathrm{Al}_{2} \mathrm{O}_{3}$ content decreases and, accordingly, on the $\mathrm{MgO} / \mathrm{FeO} * / \mathrm{Na}_{2} \mathrm{O}+$ $\mathrm{K}_{2} \mathrm{O}$ diagram the high-alumina basalts of spreading zones and zones of transform faults are in association with the least differentiated rocks with the highest $\mathrm{MgO}$ content.

Thus parental melts of deep sea trench basalts, and in an even larger degree island arcs, evidently are derivatives of oceanic tholeiitic magma, which evolved under conditions resulting either in fractionation and accumulation of $\mathrm{Al}_{2} \mathrm{O}_{3}$-rich phases in some parts of the magma chamber or in assimilation by magma of the aluminous crust material.

The transitional (to judge by the number of features) chemical composition of normal and high-alumina basalts in Hole 487 from typical ocean basalts to island arc basalts indicates, from my point of view that the basalts in Hole 487 were formed in the transitional zone between the ocean and the island arc volcanic belt of the American Cordilleras-that is, in the Middle America Trench.

\section{REFERENCES}

Anderson, R. N., Claque, D. A., Klitgord, K. D., et al., 1975. Magnetic and petrologic variation along the Galapagos spreading center and their relation to the Galapagos melting anomaly. Geol. Soc. Am. Bull., 86:683-694.

Batiza, K., Rosendahl, B. R., and Fisher, R. L., 1977. Evolution of oceanic crust Part III. Petrology and chemistry of basalts from the East Pacific Rise and Siqueiros fracture zone. J. Geophys. Res., 82:265-276.

Dickinson, W. R., 1970. Relations of andesites, granites and derivative sandstones in arc-trench tectonics. Rev. Geophys. Space Phys., 8:813-860.

Dmitriev, Y. I., in press. Basalts from the East Pacific Rise near $9^{\circ} \mathrm{N}$ drilled on DSDP Leg 54 compared with marginal-basin and oceanisland basalts. In Hekinian, R., Rosendahl, B., et al., Init. Repts. DSDP, 54: Washington (U.S. Govt. Printing Office), 695-304.

Dmitriev, Y. I., Solovova, I. P., Dolinina, Y. V., et al., 1979. Petrologia basitov Philippinskogo morya po dannim glubokovodnogo burenia. Iz. Akad. Nauk. SSSR Ser. Geol., N4:19-33.

Ewart, A., and Bryan, W. B., 1972. Petrography and geochemistry of the igneous rocks from Eua, Tongan Islands. Geol. Soc. Am. Bull., 83:3281-3298. 
Fitton, J. G., 1971. The generation of magma in island arcs. Earth Planet. Sci. Lett., II:63-67.

Green, T. H., and Ringwood, A. E., 1968. Genesis of the calc-alkaline igneous rock suite. Contrib. Mineral. Petrol., 18:105-162.

Hey, R., 1977. Tectonic evolution of the Cocos-Nazca spreading center. Geol. Soc. Am. Bull., 88:1404-1420.

Hey, R., Johnson, G. L., and Lowrie, A., 1977. Recent plate motions in the Galapagos area. Geol. Soc. Am. Bull., 88:1385-1403.

Larson, E. E., Reynolds, R. L., Merrill, R., et al., 1974. Major-element petrochemistry of some extrusive rocks from the volcanically active Mariana Island. Bull. Volcanol., 38:361-377.

Leonova, L. L., Popolitov, E. I., Volinets, O. N., et al., 1978. Tipi chetvertichnich basaltov Kamchatki v svyasi s problemoi pervichnich magm. Petrologicheskie issledovaniya basitov ostrovnich dug: Moscow (Institute of the Earth's Physics), pp. 157-176.

Lopez-Escobar, L., Frey, F. S., and Vergaza, M., 1977. Andesites and high-alumina basalts from the central south Chile High Andes: Geochemical evidence bearing on their petrogenesis. Contrib. Mineral. Petrol., 63(No. 3):203.
Moore, J. C., Watkins, J. S., Shipley, T. H., et al., 1979. Progressive accretion in the Middle America Trench, Southern Mexico. Nature, 281:638-642.

Pichler, H., and Weyl, R., 1973. Petrochemical aspects of Central American magmatism. Geol. Rundsch., 62(2):357-396.

Rudnik, G. G., 1976. Magmaticheskie i metamorphicheskie porodi vpadini Chessa. Geologo-Geophisicheskie issledovaniya v yugovostochnoi chasti Tichogo okeana: Moscow (Nauka), pp. 116-125.

Stark, J. T., 1963. Petrology of the volcanic rocks of Guam. Geol. Sur. Prof. Paper 403-C.

Stoiber, R. E., and Carr, M. J., 1974. Quaternary volcanic and tectonic segmentation of Central America. Bull. Volcanol., 37(No. 3):304-325.

Yeats, R. S., Forbes, W. C., Heath, G. R., et al., 1973. Petrology and geochemistry of DSDP Leg 16 basalts, Eastern Equatorial Pacific. In van Andel, Tj. H., Heath, G. R., et al., Init. Repts. DSDP, 16: Washington (U.S. Govt. Printing Office), 617-640.

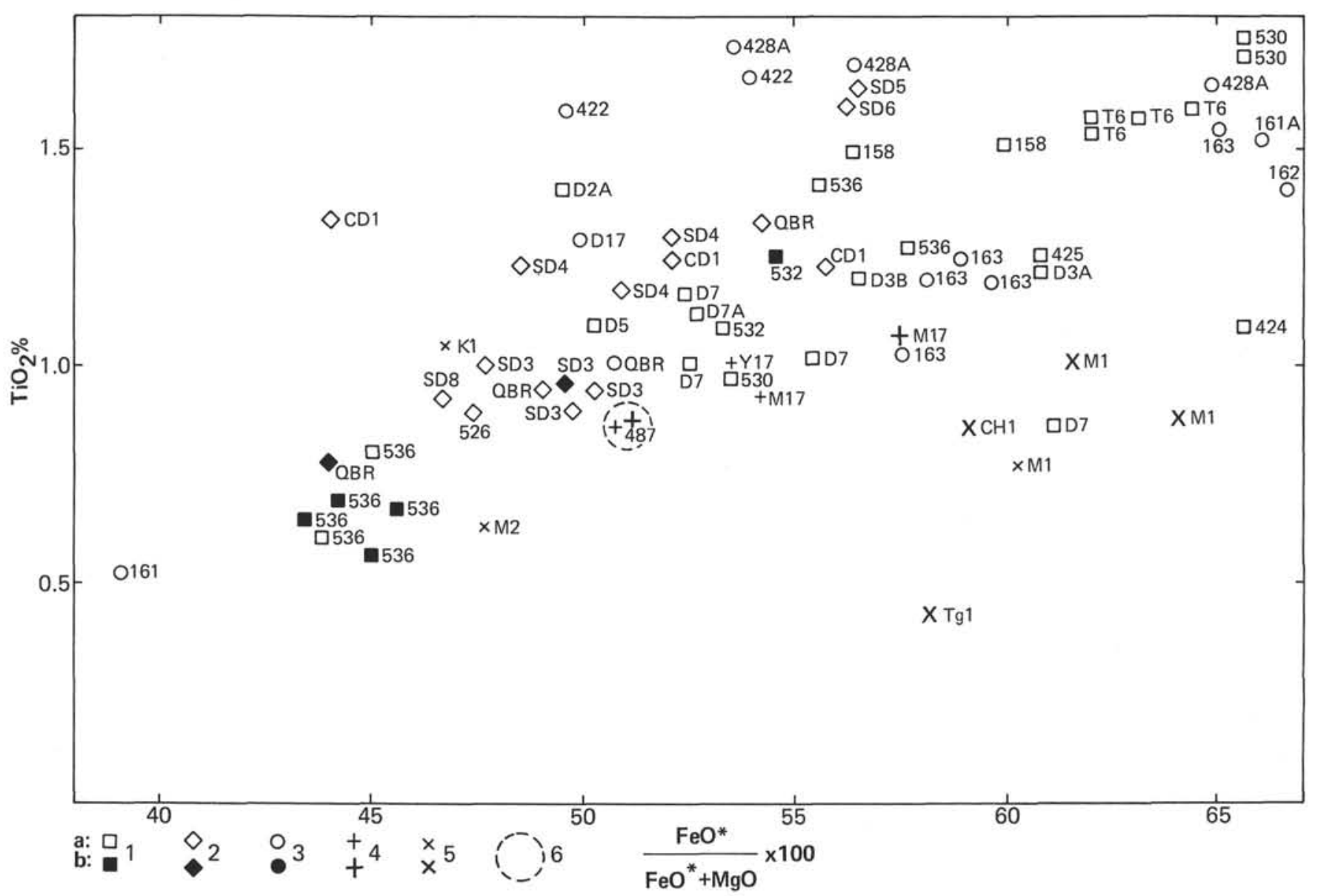

Figure 3. $\mathrm{TiO}_{2}-\left(\mathrm{FeO}^{*} / \mathrm{FeO}^{*}+\mathrm{MgO}\right) \times 100$ in Pacific basalts of various morphostructures. $(1=$ zones of spreading, $2=$ transform faults, $3=$ flanks of the East Pacific Rise, $4=$ deep sea trenches, $5=$ island arcs, $6=$ basalts in Hole 487 . a (upper line) $=$ normal tholeitic basalts, $b$ (lower line) $=$ high-alumina tholeiitic basalts. Analyses [some of the following symbols appear only in Figs. 4 and 5]: $1=$ zones of spreading, Galapagos spreading zone: D2A, D3B, D5, D7, D7A, D17, T6 [Anderson et al., 1975], 424, 425 [Dmitriev, in press, analyst, Y. V. Dolinina], 530, 532, 536 [Rudnik, 1976], 158 [Yeats et al., 1973]. 2 = transform faults, Siqueiros Zone fault: CD1, D1, D3, D4, D5, D6, D8 [Batiza et al., 1977 ]. 3 = flanks of the East Pacific Rise: 422, 428A [Dmitriev, in press, analyst, Y. V. Dolinina], 161, 162, 163 [Yeats, et al., 1973 ]. $4=$ deep sea trenches: M17-Mariana Trench, Y17-Yap Trench [Dmitriev, Leg 17 of Dmitriy Mendeleev, analyst, Y. V. Dolinina]. $5=$ island arcs: K1-Kamchatka [Leonova et al., 1978] M1 (Larson et al., 1974], M2 [Stark, 1963]-Mariana Arc Tg1 (Ewart and Bryan, 1972) - Tonga [Lopez Escobar et al., 1977] $\mathrm{CH} 1-$ Chilian Cordilera. 


\section{Y. I. DMITRIEV}

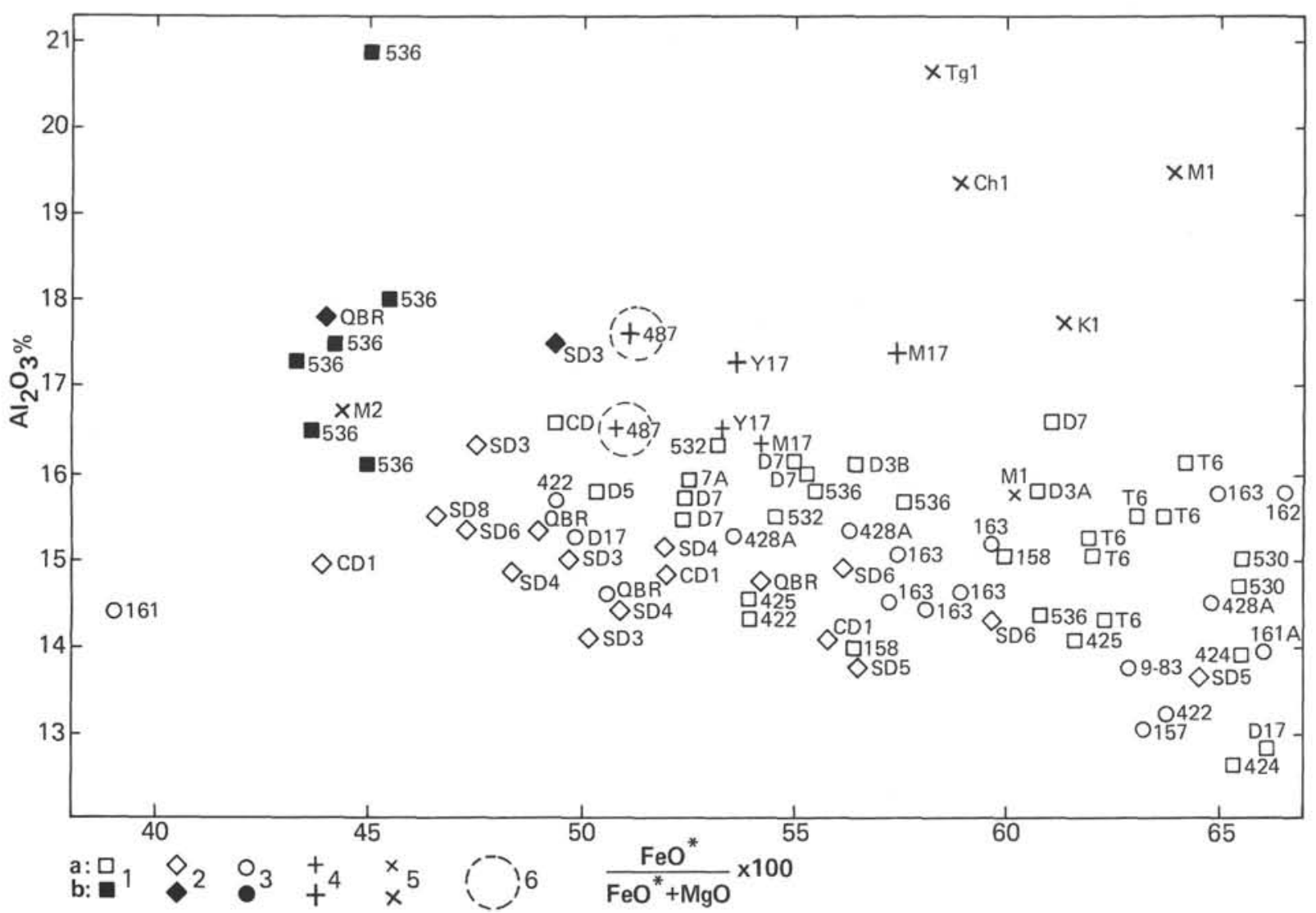

Figure 4. $\mathrm{Al}_{2} \mathrm{O}_{3}+\mathrm{FeO}^{*} / \mathrm{FeO}^{*}+\mathrm{MgO} \times 100$ in Pacific basalts of various morphostructures. (Legend and analyses same as in Fig. 3.)

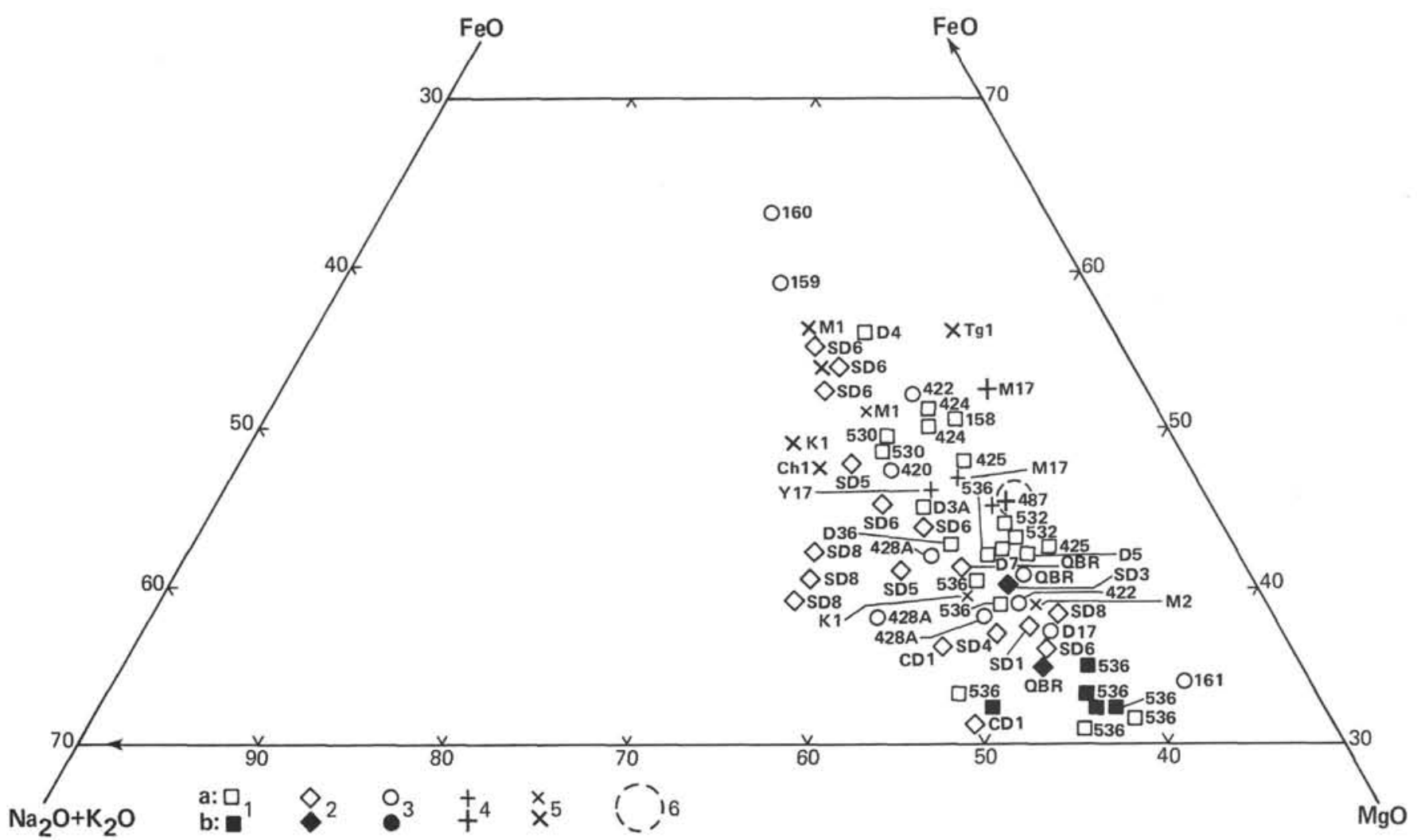

Figure 5. $\mathrm{MgO} / \mathrm{FeO}^{*} / \mathrm{Na}_{2} \mathrm{O}+\mathrm{K}_{2} \mathrm{O}$ in Pacific basalts of various morphostructures. (Legend and analyses same as in Fig. 3.) 